\title{
SUBMERGED SPELEOTHEMS - EXPECT THE UNEXPECTED. EXAMPLES FROM THE EASTERN ADRIATIC COAST (CROATIA)
}

\author{
POTOPLJENA SIGA - PRESENETLJIVI REZULTATI ANALIZ \\ VZORCEV IZ VZHODNE OBALE JADRANA (HRVAŠKA)
}

\author{
Maša SURIĆ ${ }^{1}$, Branko JALŽIĆ ${ }^{2}$, Donat PETRICIOLI ${ }^{3}$
}

\begin{abstract}
UDC 551.44(497.5)

Maša Surić, Branko Jalžić \& Donat Petricioli: Submerged speleothemes - expect the unexpected. Examples from the eastern Adriatic coast (Croatia)

With the intention of reconstructing Late Pleistocene - Holocene sea-level changes along the Eastern Adriatic coast, a series of speleothems were collected from several submerged caves and pits, in order to constrain periods of their deposition and ceased growth related to sea-level fluctuations. For that purpose, stalagmites provide more reliable records than stalactites, due to their successive layers deposited perpendicularly to the growth direction. Therefore, stalagmites have been collected preferably. But, two of 17 speleothems displayed unexpected interior morphology - speleothem L-1 collected at the depth of $1.5 \mathrm{~m}$ in Medvjeđa spilja Cave on Lošinj Island, and speleothem M-25 from Pit near Iški Mrtovnjak Islet collected at the depth of $25 \mathrm{~m}$. Both of the samples were taken from the cave floor, in the growth position of the stalagmite. But the insight into the perpendicular cut with evident central tube revealed their true (stalactitic) origin and additional confirmations were obtained by longitudinal cut and U-Th and ${ }^{14} \mathrm{C}$ dating. Just as the causes of their breakdowns were probably different, so were their falls; speleothem M 25 (together with several other speleothems around it) stuck in the marine sediment in its primary position, while L-1 turned upside-down and even continued crystallizing during the lower sea level. These events are possible in the continental caves, as well. Evidently, it is much easier to recognize and avoid these problems in air-filled caves than in the submarine ones where the speleothems are almost always covered with marine overgrowth, which disguises their outer morphology. Additionally, the bases of the stalagmites are also sometimes covered with marine sediment, which makes correct estimation rather difficult.
\end{abstract}

Keywords: submerged speleothems, Adriatic Sea, Croatia.

Izvleček

UDK 551.44(497.5)

Maša Surić, Branko Jalžić \& Donat Petricioli: Potopljena siga - presenetljivi rezultati analiz vzorcev iz vzhodne obale Jadrana (Hrvaška)

$\mathrm{Z}$ namenom rekonstrukcije sprememb morske gladine $\mathrm{v}$ poznem Pleistocenu in Holocenu v vzhodnem Jadranu, smo vzorčili sigo $\mathrm{v}$ potopljenih jamah in breznih na različnih lokacijah. Pri tem smo predvideli, da so obdobja rasti in stagnacije sige povezana s položajem morske gladine. Ker je prirastek stalagmitov vedno pravokoten na obstoječo podlago, nudijo stalagmiti primernejši zapis dogodkov kot stalaktiti. zato smo vzorčili predvsem stalagmite. Pri dveh izmed sedemnajstih vzorcev, L-1, nabran na globini 1,5 m v Medveđi jami na otoku Lošinj in vzorec M-25, vzet iz globine $25 \mathrm{~m}$ v breznu pri otočku Iški Mrtovnjak, smo opazili precej nenavadno notranjo strukturo. Oba sta bila na jamskem dnu v položaju stalagmita, a sta tako prečni in podolžni rez pokazala, da gre v resnici za stalaktit. To so potrdile tudi U-Th in ${ }^{14} \mathrm{C}$ datacije. Vzrok in način padca obeh kapnikov je bil različen. M-25 je skupaj z več kapniki obtičal v morskem sedimentu v izvirni legi, medtem ko je bila lega L-1 obrnjena, kapnik pa je še naprej rastel v obdobju nizke gladine morja. Podobne dogodke lahko pričakujemo tudi v jamah na kopnem. V vsakem primeru pa take kapnike v podmorskem okolju težje opazimo saj sta njihova prvotna oblika in položaj velikokrat zamaskirana $\mathrm{z}$ različnimi morskimi sedimenti. Ključne besede: potopljeni kapniki, Jadransko morje, Hrvaška.

\footnotetext{
${ }^{1}$ Department of Geography, University of Zadar, Tuđmanova 24 i, 23000 Zadar, Croatia, Fax.: +385 23311 282, e-mail: msuric@unizd.hr

${ }^{2}$ Croatian Natural History Museum, Demetrova 1, 10000 Zagreb, Croatia, e-mail: bjalzic@yahoo.com

${ }^{3}$ DIIV, Obala Petra Lorinija bb, 23281 Sali, Croatia, e-mail: dpetricioli@diiv.hr
}

Received/Prejeto: 11.08.2007 


\section{INTRODUCTION}

Speleothems are typical subaerial features, so their occurrence in presently submerged (submarine) caves is irrefutable evidence of former low sea levels. Since the 1970s (Spalding \& Mathews, 1972; Harmon et al., 1978; Gascoyne et al., 1979), a series of exploration have been based on submerged speleothems as indicators of low sea-level stands. e.g. on Bahamas (Richards et al., 1994; Lundberg \& Ford, 1994), on Balearic Islands (Fornós et al., 2002; Onac et al., 2006), on the Eastern Adriatic coast (Vrhovec et al., 2001; Surić et al., 2005a), etc. High sea-level stands, i.e. the latest possible time of cave flooding caused by sea-level rise can be determined by dating biogenic overgrowth that usually covers the speleothems in marine environment (Alessio et al., 1992; Antonioli \& Oliverio, 1996). Furthermore, if submerged speleothems contain remnants of marine organisms within the speleothem body, episodes of high sea level can be revealed

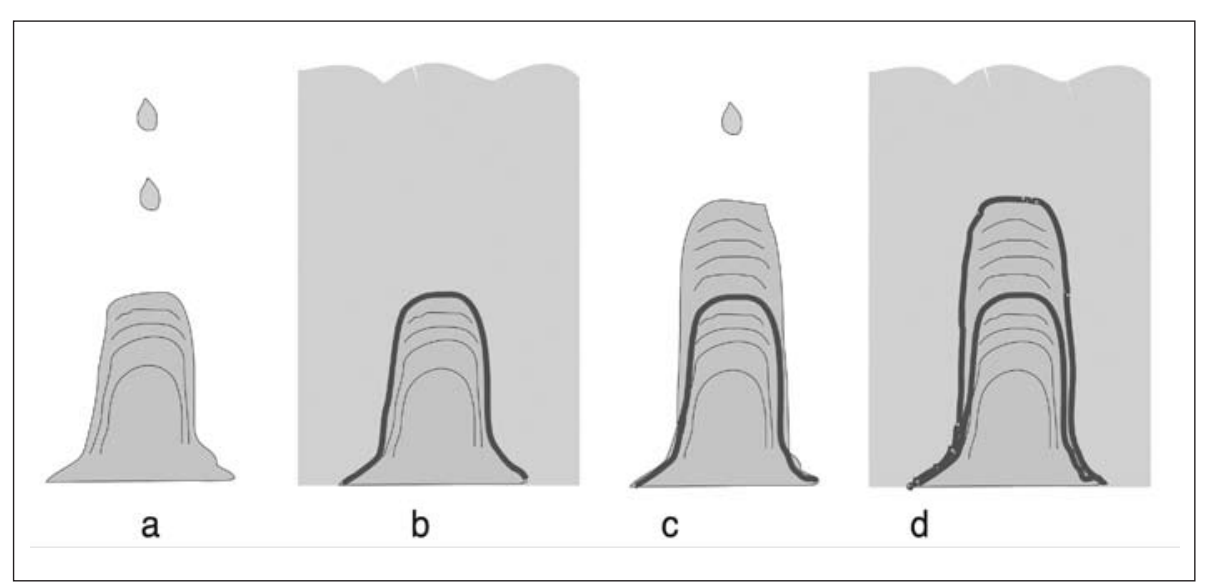

Fig. 1: Deposition of carbonate flowstone in subaerial conditions during low sea-level stand (a and c) and its cessation with biogenic encrustation (red layer) in marine environment in the periods of high sea level ( $b$ and $d)$.
(Fig. 1). Based on that fact, 215-ka history of sea-level oscillations was reconstructed on the Tyrrhenian Sea coast (Bard et al., 2002; Antonioli et al., 2004).

In order to constrain the periods of speleothem deposition and ceased growth connected with sea-level fluctuations, radiometric dating of submerged speleothems is usually employed. For that purpose, stalagmites provide better stratigraphic resolution and more reliable records than stalactites due to their successive layers deposited perpendicularly to the growth direction (Hill \& Forti, 1997). Besides, to avoid problems with ion mobilisation characteristic for stalactites, in various geochronological studies and palaeoenvironmental reconstructions, stalagmites are collected preferably (Richards \& Dorale, 2003). Hence, we used such sampling strategy in recent palaeoenvironmental study on the eastern Adriatic coast with the aim to reconstruct Late Pleistocene - Holocene relative sea-level changes (Surić, 2006). Yet, in spite of careful sampling, we encountered a problem of misleading collapsed stalactites that we had not expected. An overview of the researches on collapsed speleothems is given by Forti (1997), but only those related to earthquake reconstructions, not as a sampling problem.

\section{STUDY AREA AND SAMPLING}

Eastern Adriatic coast is locus typicus of Dalmatian coast - a flooded concordant coast characterized by chains of islands formed by Late Pleistocene - Holocene sea-level inundation of coast-parallel ridges and valleys (Kearey, 1996). Its genesis started in Mesozoic in form of carbonate platform which was subsequently disintegrated and uplifted during the Alpine orogeny due to subduction of African plate under the Eurasian continent (Vlahović et al., 2002, 2005). Emerged carbonate complex was intensively karstified and repeatedly (partially) flooded during the Quaternary sea-level fluctuations. Late Pleistocene - Holocene sea-level rise of $121 \pm 5$ m (Fairbanks, 1989) submerged vast part of karstified area and formed the recent coast. Along with other presently submerged karst forms like karrens, submerged karst springs, river canyons, etc. (Surić, 2005), more than 230 caves were discovered along the eastern Adriatic coast, and over 140 of them contain speleothems (Surić, 2006), potential material for subsequent researches.

Within a larger study, in order to encompass a wide range of sea-level stands, speleothems were collected from the depths of $1.5 \mathrm{~m}$ below mean sea level (b.m.s.l.) to $41.5 \mathrm{~m}$ b.m.s.l. from seven submerged karst features: two caves, four pits and one vrulja (submarine spring), 


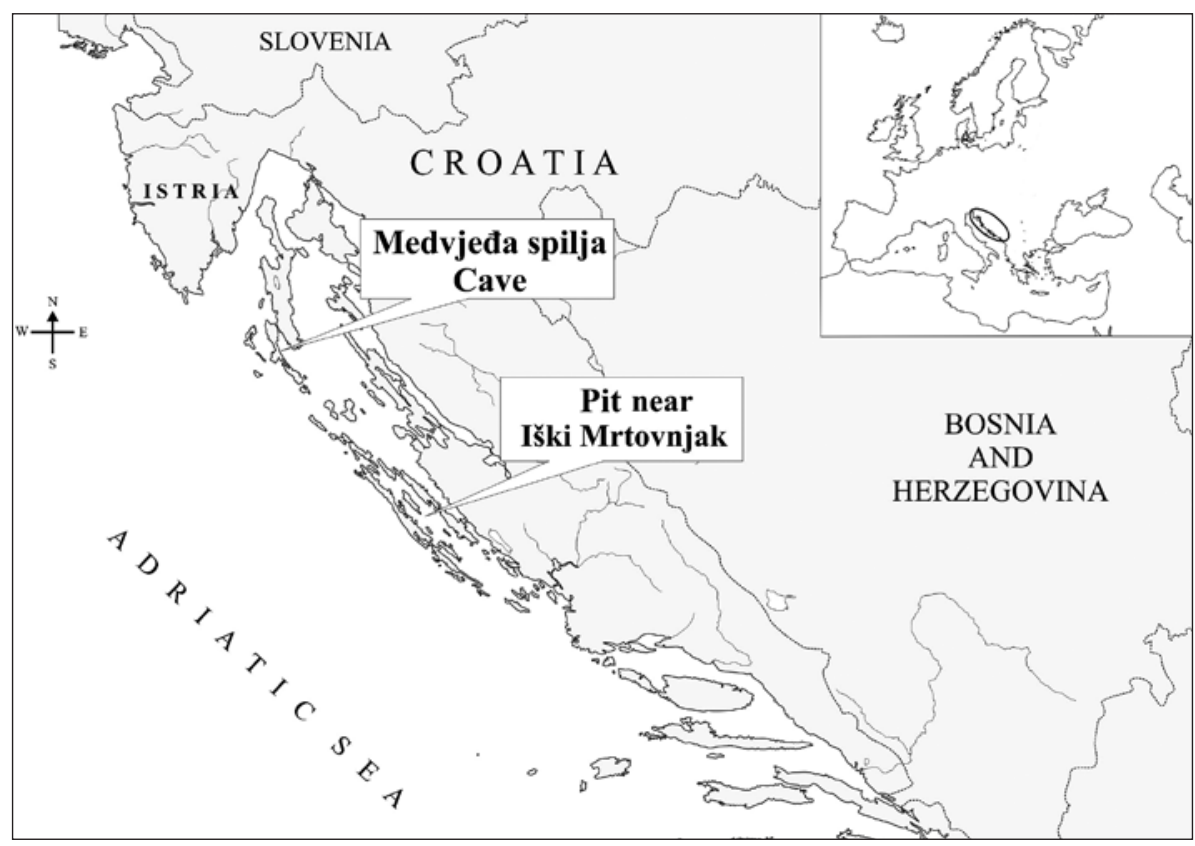

all located along the Croatian coast (Surić, 2006). Sampling was provided by SCUBA divers. Among 17 collected speleothems, two of them showed unexpected interior morphology. Those were speleothem L-1 from Medvjeđa spilja Cave on Lošinj Island, and speleothem M-25 from the Pit near Iški Mrtovnjak Islet (Fig. 2).

Fig. 2: Study area with the investigated locations: Medvjeda spilja Cave on Lošinj Island and Pit near Iški Mrtovnjak Islet.

\section{MEDVJEĐA SPILJA CAVE}

Medvjeđa spilja Cave, situated on the eastern coast of Lošinj Island, was formed along vertical fissure in Upper Cretaceous well bedded limestones (Jalžić, 2005). It is an anchialine cave with the entrance $17.5 \mathrm{~m}$ above mean sea level, $55 \mathrm{~m}$ from the coast (Fig 3a). Presumed primary entrance is $8 \mathrm{~m}$ b.m.s.l., buried with collapsed material,

\section{MEDVJEĐA ŠPILJA CAVE - LOŠINJ ISLAND}

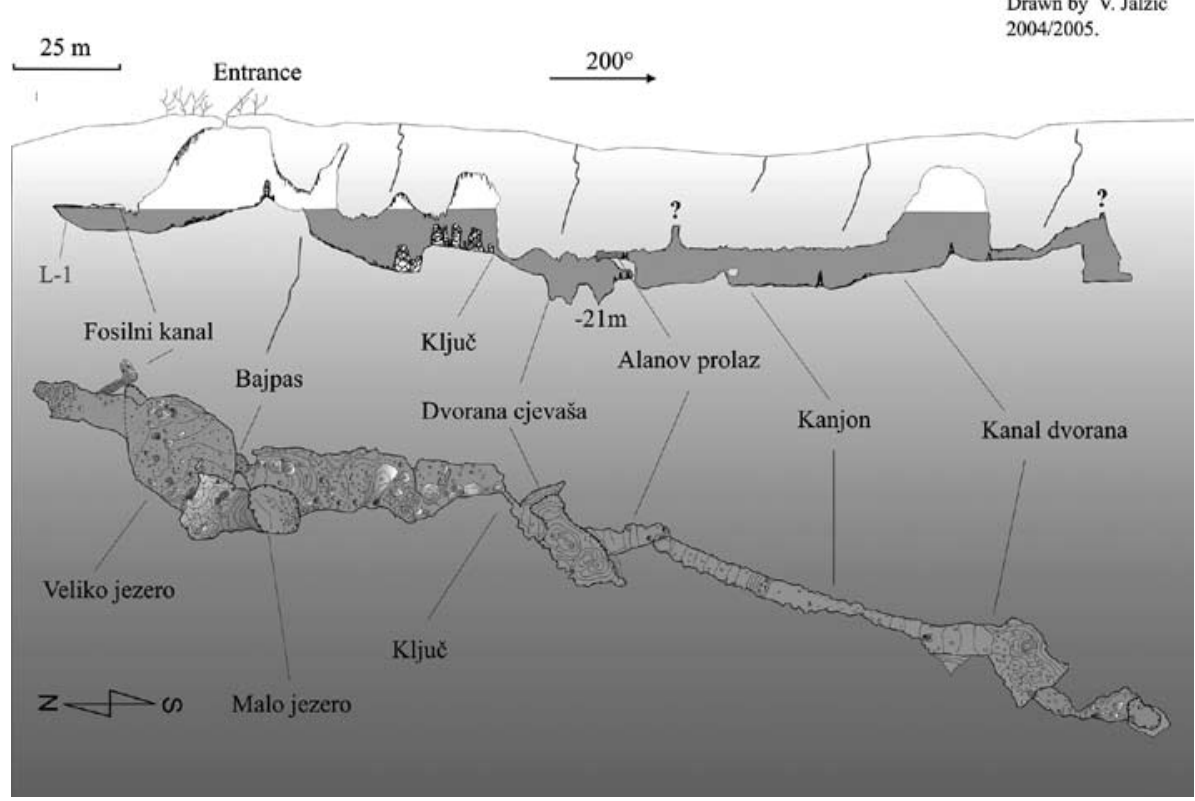

and the circulation with the open sea, with evident tidal oscillations, is established through fissures and channels in the karstified bedrock.

Speleothem L-1 (21.5 cm long) was collected from the depth of $1.5 \mathrm{~m}$ b.m.s.l. in the growth position of stalagmite, chosen between several similar speleothems from the same base flowstone. But already perpendicular section with central tube (Fig. 3c) showed that the origin of that speleothem was stalactitic, and longitudinal cut confirmed it, as well (Fig $3 b)$. According to the differences in morphology and the colour of the carbonate, we can presume two growth phases. The inner part was deposited as a stalactite, while the outermost bright part of the speleothem grew in the acicular (needle-like) form, apparently in different con-

Fig. 3: a) Cross-section of Medvjeda spilja Cave showing the location of speleothem L-1. 


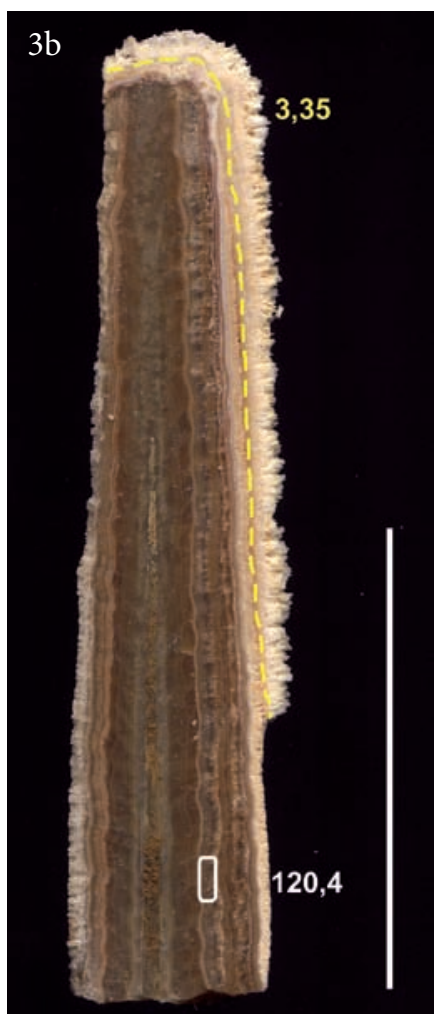
tube. of the central tube was filled with the youngest carbonate that forms needle-like cover. Lack of marine overgrowth

ditions. Major part of the central tube of this speleothem was preserved unfilled, which can be traced all along the longitudinal section as a small channel. Only at the top of the speleothem ca $0.5 \mathrm{~cm}$
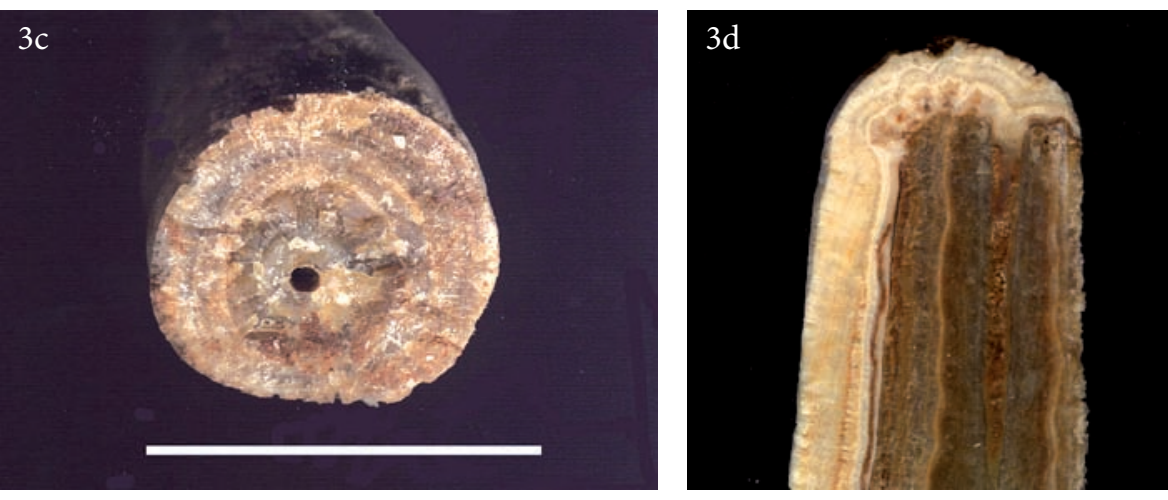

Fig. 3: b) longitudinal section of L-1 with obtained ages in $\mathrm{ka}$ (scale bar $10 \mathrm{~cm}$ ); c) perpendicular section with central tube (scale bar $5 \mathrm{~cm}$ ); d) penetration of younger carbonate into the central

indicates alternating freshwater/brackish conditions in this shallow part of the cave.

Obtained U-Th age of $120.4 \mathrm{ka}$ of inner part (Fig. $3 \mathrm{~b})$ suggests that the primary position of the speleothem L-1 in the first (stalactitic) growth phase was above the sea level associated with the MIS 5 high stand that was higher than present location of speleothem at $1.5 \mathrm{~m}$ b.m.s.l. (Surić, 2006). According to ${ }^{14} \mathrm{C}$ measurement, subsequent needle-like crystallization went on around 3.3 ka BP (Fig. 3b) (Surić, 2006).

\section{PIT NEAR IŠKI MRTOVNJAK ISLET}

Pit near Iški Mrtovnjak Islet was formed in Upper Cretaceous rudist limestones, and with its entrance $5 \mathrm{~m}$ b.m.s.l., $12 \mathrm{~m}$ offshore, it is completely within marine environment (Fig. 4a). It is rich in speleothems that are entirely covered with marine organisms belonging to the biocenosis of caves and ducts in complete darkness (Juračić et al., 2002). Ages of the analysed speleothems from the depths of $14 \mathrm{~m}, 19 \mathrm{~m}$ and $23 \mathrm{~m}$ b.m.s.l. range from $39 \mathrm{ka}$ to $202 \mathrm{ka}$ (Surić, 2006), and it seems that throughout the Late Pleistocene this pit experienced numerous submergings and recommencements of speleothem deposition.

Speleothem M-25 (46 cm long) was collected from the cave floor at the depth of $25 \mathrm{~m}$ b.m.s.l. (Fig. 4a). It was in the growth position of a stalagmite, nearby several similar, relatively long and thin speleothems (Fig. 4b). The evidence of stalactitic origin of speleothem M-25 is central tube visible in the perpendicular cut (Fig. 4c), as well as its shape - somewhat wider upper part (Fig. 4d) that is characteristic for carrot-shaped stalactite, and not for stalagmites. The difference in outer morphology between real stalagmites, which are thicker and shorter, and fallen stalactites which are thinner and longer is visible on Fig. 4b. This speleothem was completely covered with marine biogenic overgrowth, including the uppermost part where the speleothem had broken off.

\section{DISCUSSION AND CONCLUSIONS}

According to the radiometric data and inner and outer morphology of the speleothems L-1 and M-25, we can assume the scenarios of their evolution as follows:
- Speleothem L-1 grew in the form of stalactite at least during MIS 5. Afterwards, it appears that the part of the flowstone, together with several adjacent stalactites, 

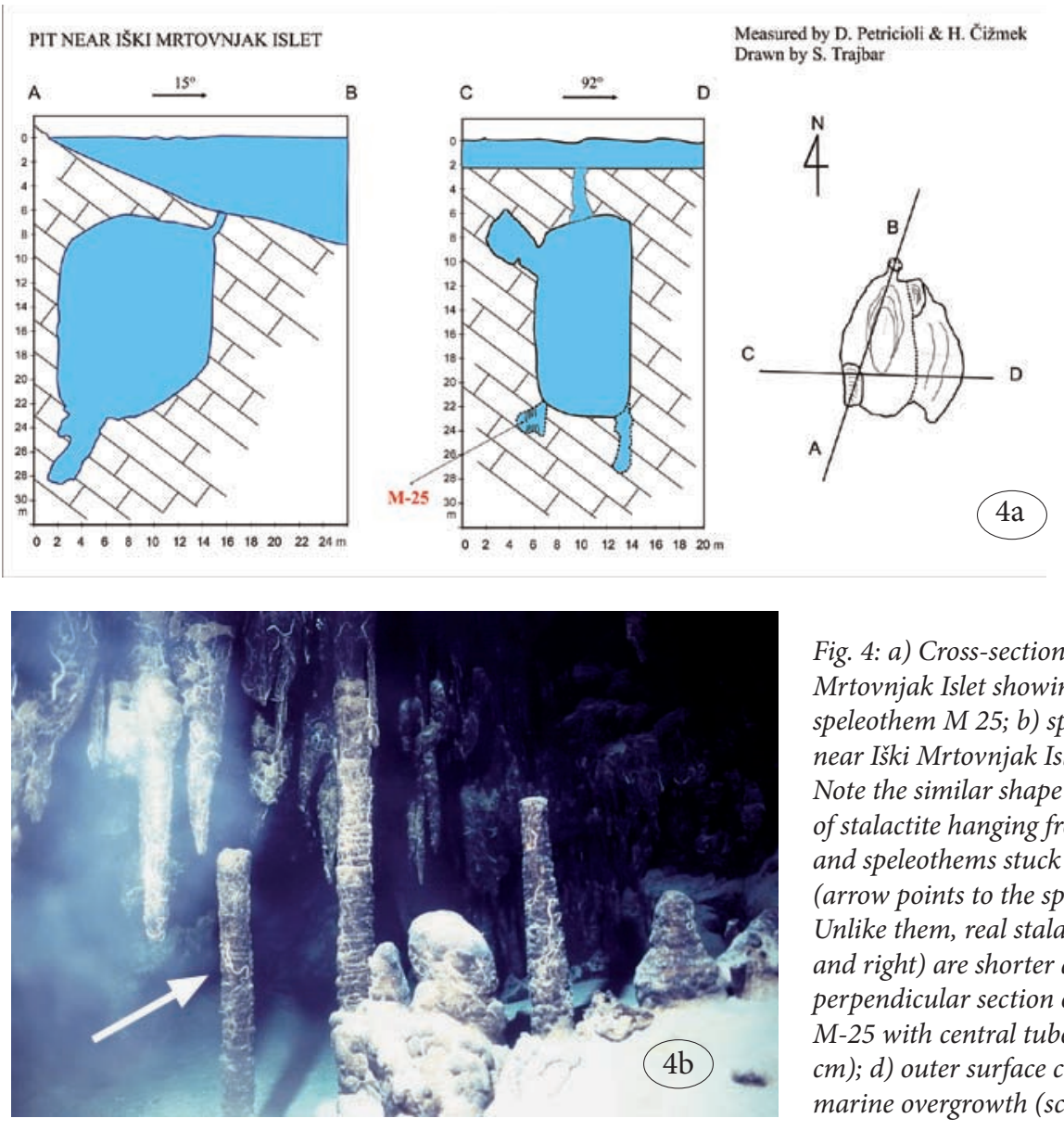

Fig. 4: a) Cross-section of Pit near Iški Mrtovnjak Islet showing the location of speleothem M 25; b) speleothems in Pit near Iški Mrtovnjak Islet $25 \mathrm{~m}$ b.m.s. l. Note the similar shape and dimensions of stalactite hanging from the roof and speleothems stuck in the mud (arrow points to the speleothem M-25). Unlike them, real stalagmites (front and right) are shorter and thicker; $c$ ) perpendicular section of speleothem M-25 with central tube (scale bar 5 $\mathrm{cm}$ ); d) outer surface covered with marine overgrowth (scale bar $10 \mathrm{~cm}$ ).

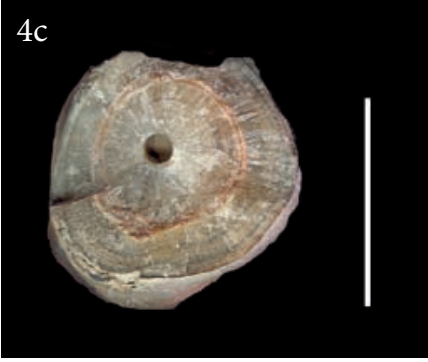

broke off from the roof and fell on the bottom in upsidedown position (Fig. 5a) where the carbonate deposition recommenced in acicular form. Penetration of younger bright carbonate into the central tube (Fig. 3d) indicates that the breakdown and immediate recommencement of carbonate deposition probably happened in subaerial environment. Finally, the speleothem L-1 was submerged by the last, Late Pleistocene - Holocene sea-level rise.

- Speleothem M-25, together with several others, after the 'stalactitic' growth apparently fell down and directly stuck into the cave or marine mud in their original position (Fig. 5b). The cause of their breakdown was either of seismic origin or the removal of the buoyant support in the period of sea-level fall. Subaerial carbonate deposition after the breakdown was not noticed, moreover, it looks like marine overgrowth covered the fresh cut soon after the breakdown.

Breakdowns of speleothems and recommencements of carbonate deposition in new position are not unusual events in caves. Rarely, speleothems keep vertical position after the fall. Yet, it is possible, so it could be misleading while sampling, especially in case of a group of fallen stalactites as in aforementioned cases. If the stalactites fall together with the flowstone layer and turn upside-down (Fig. 5a), it looks like it is their primary position, and the carrot-like stalactites could even resemble stalagmites in shape. In other cases, if the falling speleothems stuck directly in the mud (Fig. 5b), the junctures are invisible.

In marine environment, speleothem sampling is additionally complicated due to encrusting organisms. Namely, within submarine caves the speleothems are very often covered with marine overgrowth, which hides their outer morphology and possible breakage. In addition, the bases of the speleothems on the cave bottom are also sometimes overlaid with marine sediment, which makes the estimation whether it is a real stalagmite or a fallen stalactite rather difficult. Marine overgrowth also disables the assessment of quality of the speleothem fabric which is essential for most geochemical (and geochronological) analyses, since the boring organisms can heavily damage speleothem body (Fig. 6) even if the outer appearance of the sample suggests that it could be appropriate for the further measurements and analyses.

Finally, in palaeoenvironmental studies, especially in palaeotemperature reconstructions, one of the most important requirements is that the speleothems are col- 


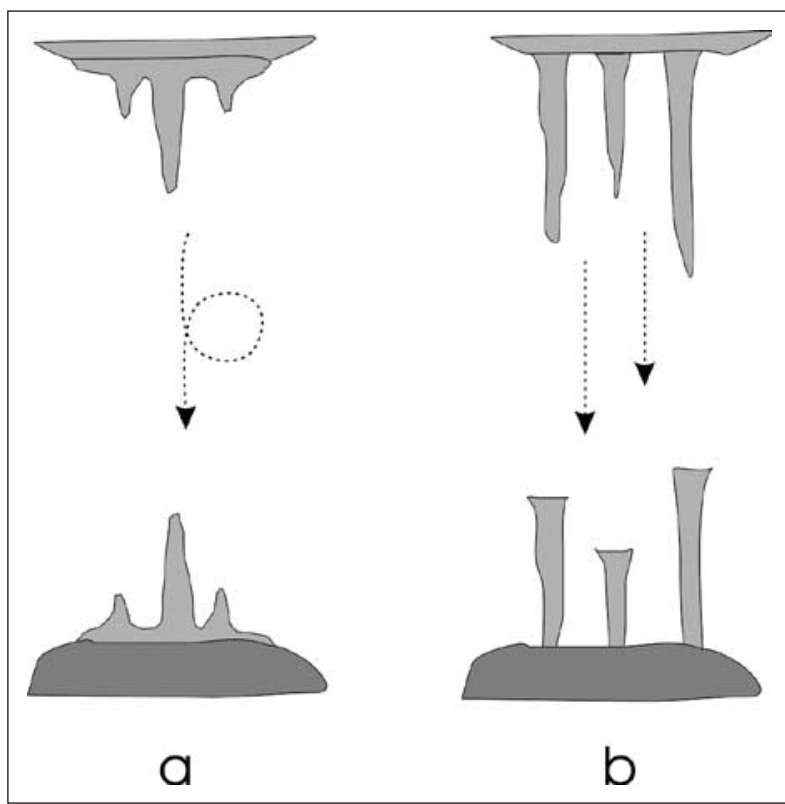

Fig. 5: Stalactites in the growth positions of stalagmites after the breakdown: a) overturned during the fall; b) stuck directly in primary position.

lected from the deep interior of the cave, in order to avoid the effect of kinetic isotopic fractionation and obtain homogenized $\delta^{18} \mathrm{O}$ signal (Ford, 1999). But, due to the objective risks of speleo-diving in distant parts of the caves, speleothems in this study were mostly sampled from approachable parts, so the recorded $\delta^{18} \mathrm{O}$ signal could not have been regarded as palaeotemperature record (Surić et al., 2005b).

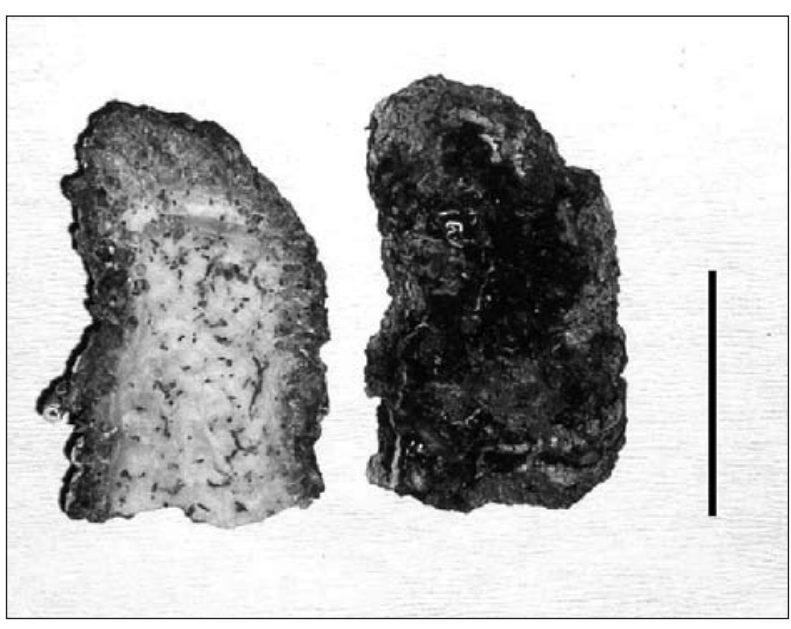

Fig. 6: Longitudinal section of stalagmite B-28 from the Pit in Lučice Bay on Brač Island (from the depth of $28 \mathrm{~m}$ b.m.s.l.) heavily devastated by boring marine organisms (scale bar $5 \mathrm{~cm}$ ) (from Surić, 2006).

In conclusion, all the limits and problems present in the process of speleothem sampling in air-filled caves are even more pronounced within the submerged ones, and with the addition of 'unexpected traps', submarine explorations can sometimes be quite uncertain and indecisive. Of course, by cautious approach and attentive sampling, aforementioned situations could be recognized and avoided.

\section{ACKNOWLEDGEMENTS}

Ministry of Science, Education and Sport of Republic of Croatia supported this research (Projects: 269-26930841177 Geographical features in the development of Croatian coastal regions, 119-0362975-1226 Research of threatened marine habitats in the coastal submerged karst of Croatia, 119-1191152-1169 Recent sediments and fossil environ- ments of the Adriatic coastal zone). We express our gratitude to Srećko Trajbar and Vedran Jalžić for the help during field work and for drawings. We would also like to thank the reviewers for useful comments and suggestions. 


\section{REFERENCES}

Alessio, M., Allegri, L., Antonioli, F., Belluomini, G., Ferranti, L., Improta, S., Manfra, L. \& Proposito, A., 1992: Risultati preliminari relativi alla datazione di speleotemi sommersi nelle fasce costiere del Tirreno centrale.- Giornale di Geologia, ser. 3., 54/2, 165-193.

Antonioli, F. \& Oliverio, M., 1996: Holocene sea-level rise recorded by a radiocarbon-dated mussel in a submerged speleothem beneath the Mediterranean Sea.- Quaternary Research, 45, 241-244.

Antonioli, F., Bard, E., Potter, E.K., Silenzi, S. \& Improta, S., 2004: 215-ka history of sea-level oscillations from marine and continental layers in Argentarola Cave speleothems (Italy).- Global \& Planetary Change, 43(1-2), 57-78.

Bard, E., Antonioli, F. \& Silenzi, S., 2002: Sea-level during the penultimate interglacial period based on a submerged stalagmite from Argentarola Cave (Italy).- Earth and Planetary Science Letters, 196 (3-4), 135-146.

Fairbanks, R. G., 1989: A 17000-year glacio-eustatic sea level record: influence of glacial melting rates on the Younger Dryas event and deep-ocean circulation.Nature, 342, 637-642.

Ford, D., 1997: Dating and Paleo-Environmental Studies of Speleothems. In: C. Hill \& P. Forti (Eds.), Cave Minerals of the World, $2^{\text {nd }}$ ed., National Speleological Society, Huntswille, 271-284.

Forti, P., 1997: Speleothems and Earthquakes. In: C. Hill \& P. Forti (Eds.), Cave Minerals of the World, $2^{\text {nd }}$ ed., National Speleological Society, Huntswille, 284-285.

Fornós, J. J., Gelabert, B., Ginés, A., Ginés, J., Tuccimei, P. \& Vesica, P., 2002: Phreatic overgrowths on speleothems: a useful tool in structural geology in littoral karstic landscapes. The example of eastern Mallorca (Balearic Islands).- Geodinamica Acta, 15, 113-125.

Gascoyne, M., Benjamin, G.J., Schwarcz, H.P. \& Ford, D.C., 1979: Sea-Level Lowering During the Illinoian Glaciation: Evidence from a Bahama "Blue Hole". Science, 205, 806-808.

Harmon, R.S., Schwarcz, H.P. \& Ford, D.C., 1978: Late Pleistocene Sea Level History of Bermuda.- Quaternary Research, 9, 205-218.

Hill, C. \& Forti, P., 1997: Cave Minerals. In: C. Hill \& P. Forti (Eds.), Cave Minerals of the World, $2^{\text {nd }} \mathrm{ed} ., \mathrm{Na}-$ tional Speleological Society, Huntswille, 117-227.

Jalžić, B., 2005: Najduža buža Jadrana (Medvjeđa špilja, Lošinj).- More, 124, 84-89.
Juračić, M., Bakran-Petricioli, T. \& Petricioli, D., 2002: Cessation of Karstification Due to the Sea-level Rise? Case Study of the Y-Cave, Dugi otok, Croatia. In: Grabovšek F. (Ed.): Evolution of Karst: From Prekarst to Cessation, Založba ZRC, Postojna, Ljubljana, 319-326.

Kearey, P., 1996: The New Penguin Dictionary of Geology, Penguin Books, London, p. 366.

Lundberg, J. \& Ford, D. C., 1994: Late Pleistocene sea level change in the Bahamas from mass spectrometric $\mathrm{U}$ series dating of submerged speleothem.- Quaternary Science Reviews, 13 (1), 1-14.

Onac, B., Fornós, J.J., Ginés, J., Ginés, A., Tuccimei, P., Peate, D.W. \& Björck, S., 2006: Sea-level position at $\sim 80 \mathrm{ka}$ based on phreatic overgrowths on speleothems from Mallorca. In: Onac, B., Tămaş, T., Constantin S., Perşoiu, A. (Eds.): Archives of Climate Change in Karst, Proceedings of the symposium Climate Change: The Karst Record (IV), 26-29 May 2006, Băile Herculane, Romania, Karst Water Institute, 189-191.

Richards, D. A., Dorale, J. A., 2003: Uranium-series Chronology and Environmental Applications of Speleothems. In: Bourdon, B., Henderson, G. M., Lundstrom, C. C., Turner, S. P., (Eds.): Uranium Series Geochemistry, Reviews in Mineralogy \& Geochemistry, Vol. 52, Geochemical Society, Mineralogical Society of America, 407460.

Richards, D.A., Smart, P.L. \& Edwards, R.L., 1994: Maximum sea levels for the last glacial period from $U$ series ages of submerged speleothems.- Nature, 367, 357-360.

Spalding, R.F. \& Mathews, T.D., 1972: Stalagmites from Caves in the Bahamas: Indicators of Low Sea Level Stand.- Quaternary Research, 2, 470-472.

Surić, M., 2005: Submerged karst - dead or alive? Examples from the Eastern Adriatic coast (Croatia).Geoadria, 10/1, 5-19.

Surić, M., 2006: Late Pleistocene - Holocene palaeoenvironmental changes - records from submerged speleothems from the Eastern Adriatic Sea (Croatia). PhD thesis, Faculty of Science, University of Zagreb, p. 213, Zagreb, (in Croatian).

Surić, M., Juračić, M., Horvatinčić, N. \& Krajcar Bronić, I., 2005a: Late Pleistocene - Holocene sea-level rise and the pattern of coastal karst inundation: records from submerged speleothems along the Eastern Adriatic Coast (Croatia).- Marine Geology, 214 (13), 163-175. 
Surić, M., Horvatinčić, N., Suckow, A., Juračić, M. \& Barešić, J., 2005b: Isotope records in submarine speleothems from the Adriatic coast, Croatia.- Bulletin de la Société Géologique de France, 176/4, 363-373.

Vlahović, I., Tišljar, J., Velić, I. \& Matičec, D., 2002: The Karst Dinarides are Composed of Relics of a Single Mesozoic Platform: Facts and Consequences.- Geologia Croatica, 55/2, 171-183.
Vlahović, I., Tišljar, J., Velić, I. \& Matičec, D., 2005: Evolution of the Adriatic Carbonate Platform: Palaeogeography, main events and depositional dynamics.- Palaeogeography, Palaeoclimatology, Palaeoecology, 220, 333-360.

Vrhovec, T., Mihevc, A., Lauritzen, S.E. \& Lundberg, J., 2001: O starosti potopljenih stalaktitov v jami pri otočku Galiola, Dalmacija, Hrvatska, (On the ages of the submerged stalactites from the pit near islet Galiola, Dalmatia, Croatia).- Naše jame, 43, 31-36. 